\title{
Reconstrucción compleja de la cavidad oral mediante dos colgajos simultáneos de peroné y radial
}

\section{Complex reconstruction of the oral cavity by means of the combination of two simultaneous free fibula and radial flaps}

\author{
A. Dean Ferrer1, F.J. Alamillos Granados², A. Redondo Camacho², J. Torres Corpas'2, J.J. Ruiz Masera², \\ F. Zafra Camacho ${ }^{4}$ G. Barrios Sánchez ${ }^{4}$
}

Resumen: El objetivo del presente trabajo es valorar los resultados funcionales y estéticos de reconstrucciones complejas orofaciales, realizadas mediante la asociación de dos colgajos libres simultáneos de peroné y radial. Se ha realizado este tipo de reconstrucción en tres pacientes con buenos resultados funcionales y estéticos.

La reconstrucción con dos colgajos libres está indicada en defectos complejos en los que la reconstrucción con un solo colgajo no obtendría resultados estéticos y funcionales adecuados. Cada colgajo se selecciona por sus características que lo hacen ideal para cada tipo de defecto, óseo y de partes blandas con la finalidad de conseguir un resultado estético y funcional superior al que se obtendría con un solo colgajo.

Palabras clave: Colgajos libres; Defectos oromandibulares complejos; Reconstrucción oromandibular; Colgajo libre de peroné; Colgajo libre radial; Colgajos libres simultáneos.
Abstract: The aim of this paper is to evaluate the functional and aesthetic results of complex orofacial reconstructions by means of the combination of two simultaneous free flaps (fibula osteocutaneous and radial forearm flaps). Three patients who have undergone this kind of reconstruction are presented with good functional and aesthetics results.

Reconstruction with two free flaps is indicated in complex defects in which reconstruction with a single flap would not obtain adequate aesthetic and functional results. The choice of each particular flap depends on its specific characteristics that make it ideal for the reconstruction of each particular type of defect, osseous defects and soft tissue defects, with the aim of obtaining a better result than that obtained with the use of a single flap.

Key words: Free flaps; Complex oromandibular defects; Oromandibular reconstruction; Fibula free flap; Radial free flap; Simultaneous free flaps.

\footnotetext{
1 Médico Adjunto.

Profesor asociado de la Facultad de Medicina. Universidad de Córdoba. España.

2 Médico Adjunto.

3 Médico Especialista en Cirugía Oral y Maxilofacial. Práctica privada. Córdoba.

España.

4 Médico Residente.

Servicio de Cirugía Oral y Maxilofacial.

Unidad de Reconstrucción Autotrasplante Microquirúrgico.

Hospital Universitario "Reina Sofía", Córdoba. España.

Correspondencia:

Dra. Alicia Dean

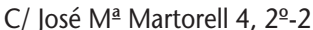

14005 Córdoba, España

E-mail: ADF10101@teleline.es
} 


\section{Introducción}

La utilización de colgajos microquirúrgicos ha permitido una gran mejora en la reconstrucción de los pacientes con cáncer de cabeza y cuello tras la cirugía ablativa, ${ }^{1,2}$ y son utilizados de forma habitual en la reconstrucción del cáncer de cavidad oral y orofaringe. Sin embargo, los defectos complejos oromandibulares siguen siendo un reto para el cirujano y un problema importante tanto desde el punto de vista funcional como estético.

Se han descrito diversos colgajos compuestos para reconstrucción oromandibular, 3,4 pero en defectos oromandibulares complejos, ningún colgajo aporta simultáneamente el ideal de tejido óseo para reconstrucción mandibular y de tejido blando para recubrimiento de superficie mucosa. ${ }^{1}$ No existe un colgajo único que combine suficiente cantidad de hueso con un tejido blando para recubrimiento mucoso que sea delgado, plegable y adaptable al contorno oral. Cada vez existen más aportaciones en la bibliografía donde se utilizan dos colgajos para solucionar el problema de las reconstrucciones oromandibulares complejas. 1,2,5-11

La combinación de varios colgajos pretende suplir los defectos que puede tener una reconstrucción única en defectos complejos. Cada colgajo se selecciona independientemente por sus características que lo hacen ideal para cada tipo de defecto, óseo y de partes blandas con la finalidad de conseguir un resultado estético y funcional superior a la utilización de un solo colgajo.

Presentamos nuestra experiencia en la reconstrucción compleja de defectos oromandibulares donde se utilizaron simultáneamente dos colgajos libres microvascularizados de peroné y radial.

\section{Casos clínicos}

Se ha realizado la reconstrucción de defectos oromandibulares complejos en tres pacientes mediante la asociación de colgajo osteocutáneo de peroné para reconstrucción mandibular y colgajo fasciocutáneo radial para reconstrucción de partes blandas, bien superficie mucosa o cobertura cutánea.

Técnica quirúrgica. En los tres casos se realizó reconstrucción primaria. Se utilizaron dos equipos quirúrgicos. El paciente se coloca en posición supina. La elevación de los colgajos y la ablación se realiza de forma simultánea. La elevación de los colgajos se realiza hasta dejarlos pediculados pero sin seccionar el pedículo, mientras se realiza la ablación. Primero se procede a la reconstrucción ósea con peroné realizando la anastómosis a los vasos receptores que se hayan seleccionado. Posteriormente se coloca el colgajo radial en posición para realizar la cobertura de partes blandas y se procede a realizar la anastómosis con los vasos receptores. En último lugar se completa la sutura de las partes blandas de la cavidad oral o cobertura externa y suspensión de tejidos blandos.

Caso 1: Paciente varón de 52 años de edad con carcinoma epidermoide de suelo de boca anterior T4, N2a, M0. La lesión oral afectaba a suelo de boca anterior, mitad anterior de lengua, suelos de boca laterales y hueso mandibular desde 37 a 47. Se realizó vaciamiento cervical bilateral radical modificado. La lesión intraoral se resecó realizando un abordaje tipo "Visor". La resección intraoral incluía una mandibulectomía segmentaria de ángu-

\section{Introduction}

The use of microsurgical flaps has permitted a great improvement in the reconstruction of patients with head and neck cancer following ablative surgery 1,2 and they are regularly used in the reconstruction of cancer of the oral cavity and oropharynx. However, complex oromandibular defects continue being a challenge for surgeons and an important problem from the functional as well as aesthetic point of view.

Various composite flaps for oromandibular reconstruction ${ }^{3,4}$ have been described, but in complex oromandibular defects, no flap can simultaneously provide the ideal bone texture for mandibular reconstruction and soft-tissue for covering a mucosal surface. ${ }^{1}$ There is no single flap that has a sufficient amount of bone together with soft-tissue for covering a mucosal area which is thin, pliable and which adapts to the oral environment. There are more and more articles in bibliographies in which two flaps are used to solve the problems arising from complex oromandibular reconstructions. $1,2,5-11$

The combination of various flaps is aimed at compensating the defects that may arise when reconstruction with a single [flap] is carried out for complex defects. Each flap is chosen independently for its characteristics, which make it ideal for each type of bone or soft-tissue defect with the aim of achieving an aesthetic and functional result that is superior to the use of a single flap.

We present our experience in complex reconstruction of oromandibular defects using two microvascularized free fibula and radial flaps simultaneously.

\section{Clinical cases}

The reconstruction of complex oromandibular defects was carried out in three patients using the combination of the fibula osteocutaneous flap for mandibular reconstruction and the radial forearm fasciocutaneous flap for soft-tissue reconstruction, either for mucosal surface or for cutaneous resurfacing.

Surgical technique: In all three cases primary reconstruction was carried out. Two surgical teams were used. The patient is placed in a supine position. The elevation of the flaps and ablation is done simultaneously. The flaps are elevated until they are pedicled, but the attachment of the pedicle is left in tact, while the ablation is performed. First bone reconstruction is carried out with fibula. Anastomosis is carried out on the receptor vessels that have been selected. Later the radial forearm flap is positioned so that soft-tissues are resurfaced and anastomosis is carried out on the receptor vessels. Lastly, suturing of soft-tissues is completed in the oral cavity or outer surface together with soft-tissue fixation.

Case 1: Male patient, 52 years old with squamous cell carcinoma of the anterior floor of the mouth T4, N2a, MO. 
lo mandibular derecho a ángulo mandibular izquierdo, glosectomía subtotal $(4 / 5)$ y resección de suelos de boca anterior y laterales con la musculatura suprahioidea. El defecto se reconstruyó con un colgajo osteocutáneo de peroné para reconstruir mandíbula realizando la osteosíntesis con barra de reconstrucción mandibular. El peroné se adaptó a la forma mandibular realizando tres osteotomías para dejar cuatro fragmentos óseos, que se fijaron a la barra de reconstrucción mediante tornillos. El colgajo fasciocutáneo radial se utilizó para reconstruir el defecto lingual. Las anastómosis microvasculares se realizaron término terminales, primero las del peroné y posteriormente las del radial. Los vasos del colgajo de peroné se anastomosaron en los vasos del lado izquierdo (arteria facial y vena yugular externa) y el colgajo radial en los vasos del lado derecho (arteria facial, tronco venoso tirolinguofacial y vena yugular externa). La piel del colgajo de peroné se utilizó para realizar la cobertura del reborde alveolar mandibular, fondo vestibular y cara lingual mandibular. El colgajo radial sirvió para realizar el recubrimiento de la zona lingual. El borde posterior de la piel del colgajo de peroné se suturó con el borde anterior de la piel del colgajo radial y formó la concavidad del nuevo suelo de boca. La tendencia habitual de los colgajos en la cavidad oral es adquirir una forma convexa. Para conseguir esa concavidad que facilita la formación de la "neolengua", se deben colocar suturas de fijación al fondo del suelo de la boca. La musculatura suprahioidea y los depresores de la mandíbula se suturaron al borde inferior de la neomandíbula, utilizando orificios de la barra de reconstrucción mandibular. Es importante recolocar y suspender la piel del mentón a la barra de reconstrucción mandibular en la zona de la neosínfisis para evitar la caída del labio inferior y mentón que provocarían una incompetencia labial. El resultado histopatológico se informó como carcinoma epidermoide moderadamente diferenciado que no alcanzaba los bordes quirúrgicos de resección. Posteriormente fue sometido a radioterapia (Figs. 1 a 7 ).

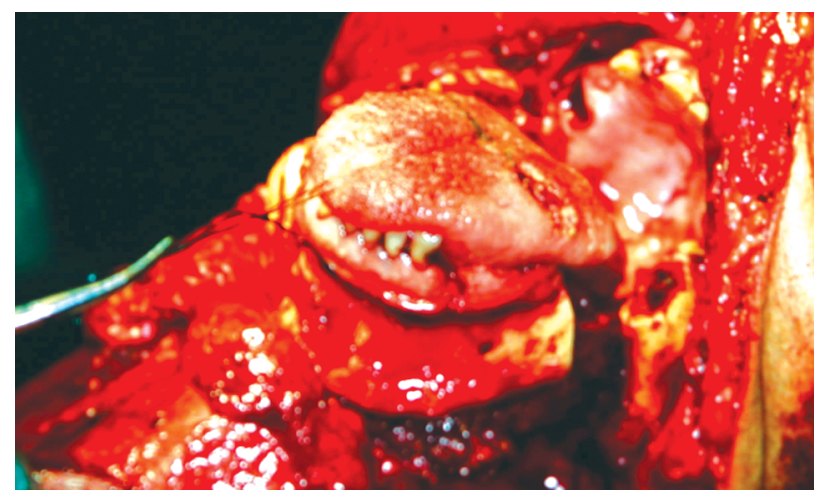

Figura 1. Caso 1. Abordaje de la lesión intraoral por medio de "Visor flap".

Figure 1. Case 1. Intraoral approach of the lesion using "Visor flap".

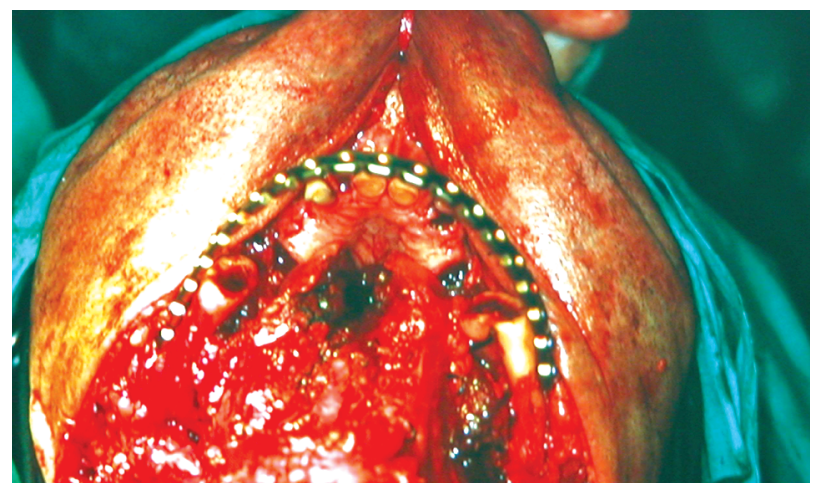

Figura 2. Tras la ablación. Vista desde la parte inferior mandibular. Se aprecia el defecto mandibular y la placa reconstrucción en posición.

Figure 2. Following ablation. View from the inferior part of the mandible. The mandibular defect can be seen with the reconstruction plate in position.

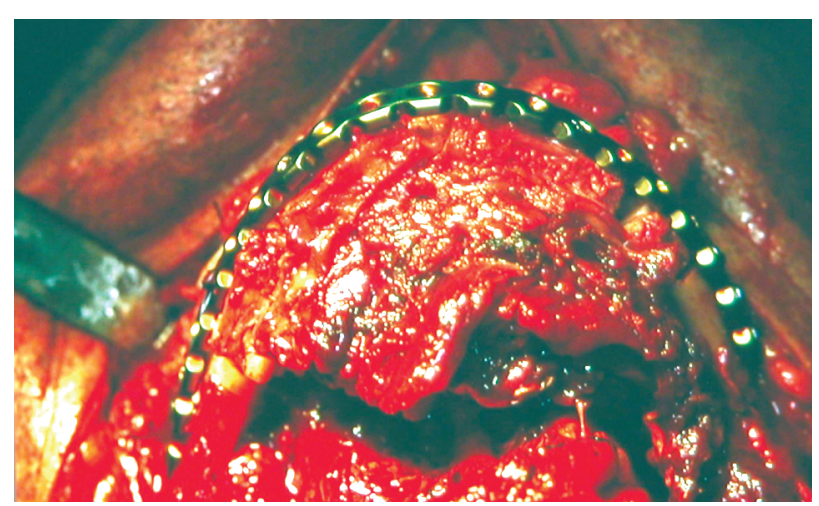

Figura 3. Colgajo osteocutáneo de peroné en posición adaptado a la barra de reconstrucción (visión inferior).

Figure 3. Fibula osteocutaneous flap in position and adapted to the reconstruction plate (inferior view).
The oral lesion was affecting the anterior floor of the mouth, anterior half of the tongue, lateral floor of the mouth and mandibular bone from 37 to 47. Bilateral modified radical neck resection was carried out. The intraoral lesion was resected using a "Visor-type" approach. The intraoral resection included a segmental mandibulectomy from the right mandibular angle to the left mandibular angle, a subtotal glossectomy (4/5) and resection of the anterior and lateral floor of the mouth including the suprahyoid muscle group. The defect was reconstructed with a fibula osteocutaneous flap for mandible reconstruction and osteosynthesis was carried out with a mandibular reconstruction plate. The fibula was adapted to the shape of the mandible by means of three osteotomies so that four bone fragments were left that were secured to the reconstruction plate using screws. The radial forearm fasciocutaneous flap was used for reconstructing the lingual defect. Microvascular end-toend anastomosis was carried out, first on the fibula [flap] and then on the radial [flap]. The vessels of the fibula flap were connected to the vessels on the left side (facial artery and external jugular vein) and the radial flap to the vessels on the right side (facial artery, thyro-lingual-facial vein trunk and external jugular vein). The skin of the fibula flap was used to resurface of the mandibular alveolar border, the back of the vestibule, and mandibular lingual surface. The radial flap was used to resurface the lingual area. The posterior border of the skin of the fibula flap was sutured with the anterior border of the skin of the radial flap to form a concave shape for the new floor of the 
Caso 2: Paciente varón de 55 años de edad con carcinoma epidermoide de suelo de boca anterior T4 N2c M0. La lesión afectaba a suelo de boca anterior, los dos tercios anteriores de la lengua, suelos de boca laterales y hueso mandibular desde premolares derechos a premolares izquierdos. La resección y reconstrucción se realizó de forma similar al caso 1. El defecto se reconstruyó con un colgajo osteocutáneo de peroné para reconstruir mandíbula realizando la osteosíntesis con barra de reconstrucción mandibular, dejando la piel del peroné para reconstruir reborde alveolar y suelo de boca anterior. El peroné se adaptó a la forma mandibular realizando dos osteotomías para dejar tres fragmentos óseos, que se fijaron a la barra de reconstrucción mediante tornillos. El colgajo fasciocutáneo de radial se utilizó para reconstruir el defecto lingual (Fig. 8). El resultado histopatológico se informó como carcinoma epidermoide moderadamente diferenciado que no alcanzaba bordes de resección. Posteriormente se instauró tratamiento radioterápico.

Caso 3: Paciente varón de 54 años de edad con antecedentes de esquizofrenia. Presentaba un carcinoma epidermoide de labio inferior con extensión a comisuras, mejilla y sínfisis mandibular. Se reconstruyó con dos colgajos simultáneos: colgajo osteocutáneo de peroné para sínfisis mandibular, reborde alveolar y parte de suelo de boca y colgajo fasciocutáneo radial con tendón del palmar largo para cara interna y externa de labio inferior, comisuras, parte de mejilla y mentón. Se realizó vaciamiento cervical bilateral supraomohioideo. La resección incluía todo el labio inferior, ambas comisuras, parte de mejilla derecha, piel del mentón y parte de piel submental cervical y mandíbula desde zona premolar derecha a zona premolar izquierda. En este caso, dada la extensión vestibular de la tumoración, se realizó la resección mandibular y posteriormente se adaptó una placa de reconstrucción mandibular tomando como referencia la relación oclusal maxilomandibular. Se realizaron dos osteotomías para colocar el hueso del peroné en el defecto, realizando la osteosíntesis de los fragmentos a la placa

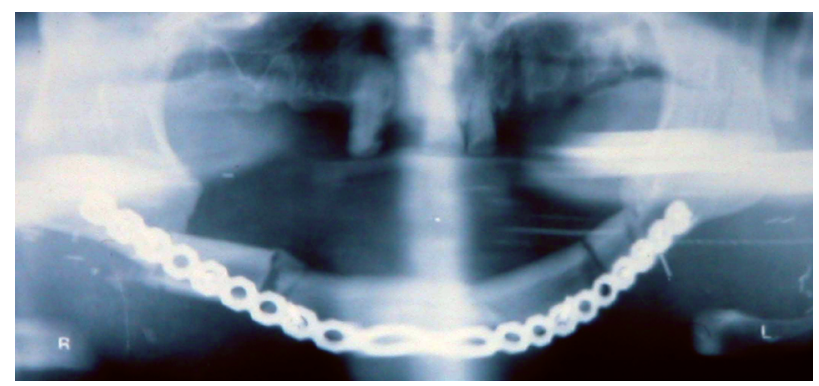

Figura 4. Ortopantomografía postoperatoria. Figure 4. Postoperative orthopantomography.

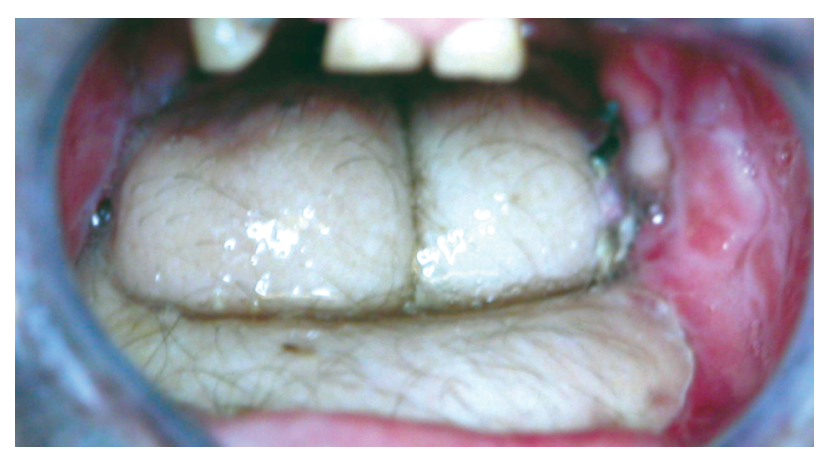

Figura 5. Aspecto intraoral de la reconstrucción de la neolengua.

Figure 5. Intraoral aspect of the reconstruction of the new tongue.

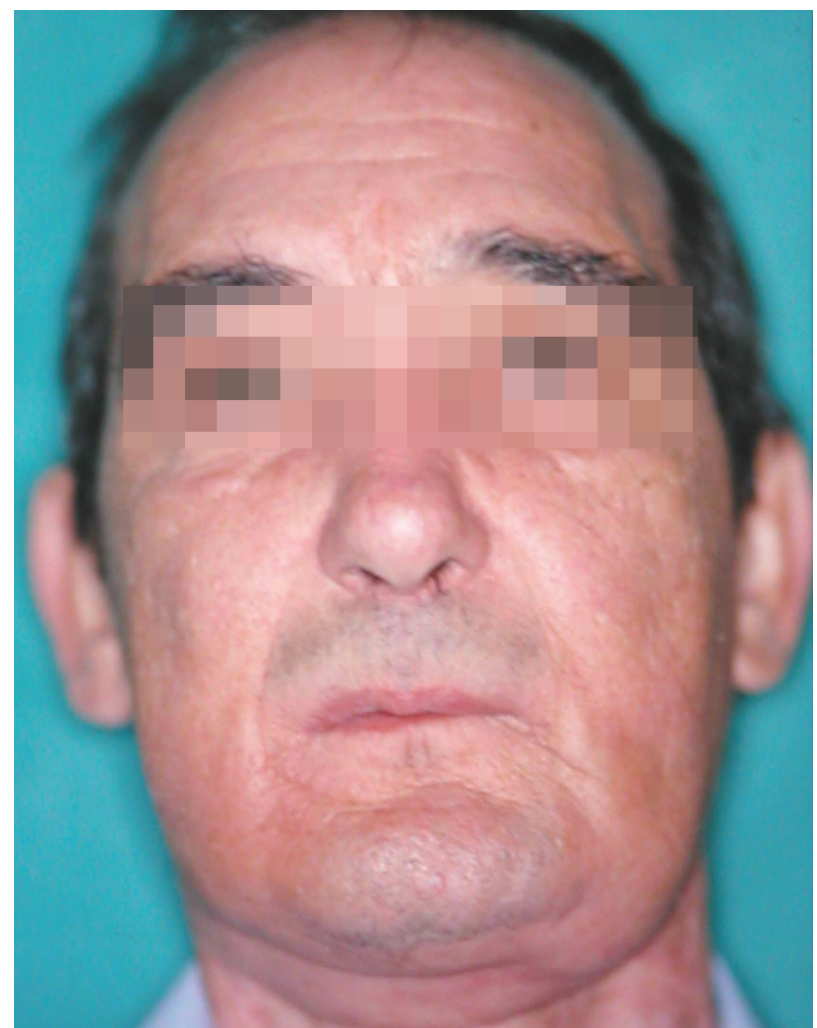

Figura 6. Resultado postoperatorio (vista de frente). Figure 6. Postoperative results (frontal view). mouth. Flaps in the oral cavity normally tend to acquire a convex form. In order to achieve this concavity, which will facilitate the formation of the "neotongue", fixation sutures should be placed on the floor of the mouth. The suprahyoid muscles and the mandible depressors were sutured to the lower border of the neomandible, using the holes in the mandibular reconstruction plate. It is important to reposition and suspend the skin of the chin from the mandibular reconstruction plate in the area of the neosymphysis in order to avoid the low lower lip and chin drooping, which would cause and labial incompetence. The histopathological result was reported as moderately differentiated squamous cell carcinoma that did not extend to the surgical margins of the resection. Later he underwent radiotherapy. Figures 1 to 7 illustrate the case. Case 2: Male patient, 55 years old, with squamous cell carcinoma on the anterior floor of the mouth T4 $\mathrm{N} 2 \mathrm{c} \mathrm{M0}$. The lesion affected the anterior floor of the mouth, the anterior two thirds of the tongue, lateral floor of the mouth and mandibular bone from the premolars on the right side to the premolars on the left. Resection and reconstruction were done in a similar way to case 1. The defect was reconstructed with a fibula osteocutaneous flap in order to reconstruct the mandible and carry out osteosynthesis with a mandibular reconstruction plate, leaving the fibula skin for reconstructing the alve- 
con tornillos. Seguidamente se realiza la anastomósis de los vasos peroneos a los vasos receptores del cuello izquierdo (arteria lingual, vena yugular externa y vena del tronco tirolinguofacial). Las anastomosis de los vasos del colgajo radial se realizaron a vasos receptores del cuello derecho (arteria tiroidea superior, vena yugular externa y vena del tronco tirolinguofacial). Posteriormente se procedió a suturar las partes blandas, doblando la piel del colgajo radial para formar el labio inferior. Se utilizó el tendón del palmar largo para realizar la suspensión de los tejidos blandos del neolabio y evitar la incompetencia labial. Posteriormente fue sometido a radioterapia (Figs. 9 a 12).

\section{Resultados}

Los resultados se han analizado valorando la duración de la cirugía, la supervivencia de los colgajos, las complicaciones, la necesidad de cirugías secundarias, la función deglutoria, la competencia oral, la dieta, la necesidad de traqueotomía permanente, la función fonatoria, la morbilidad en la zona donante, la estética y la evolución de la enfermedad.

La duración media del total de la cirugía ha sido de 11.5 horas. La evolución postoperatoria fue favorable sin pérdida de ninguno de los colgajos. El paciente 1 desarrolló una infección del lecho quirúrgico cervical izquierdo que se solucionó con tratamiento conservador.

No se realizó ninguna cirugía secundaria. La función deglutoria es adecuada sin necesidad de sonda. La dieta oral se instauró a los 10-15 días del postoperatorio. La decanulación se realizó a los 10 días de la cirugía. La competencia oral, que se valoró por la presencia de babeo (ausente, leve, moderado o severo), fue adecuada con ausencia de babeo en los dos primeros pacientes $y$ babeo leve en el tercer paciente. El habla, que se valoró como excelente (normal), buena (fácilmente inteligible), regular (inteligible con dificultad) y mala (ininteligible), fue buena en los pacientes 2 y 3 , y regular en el paciente 1 . No

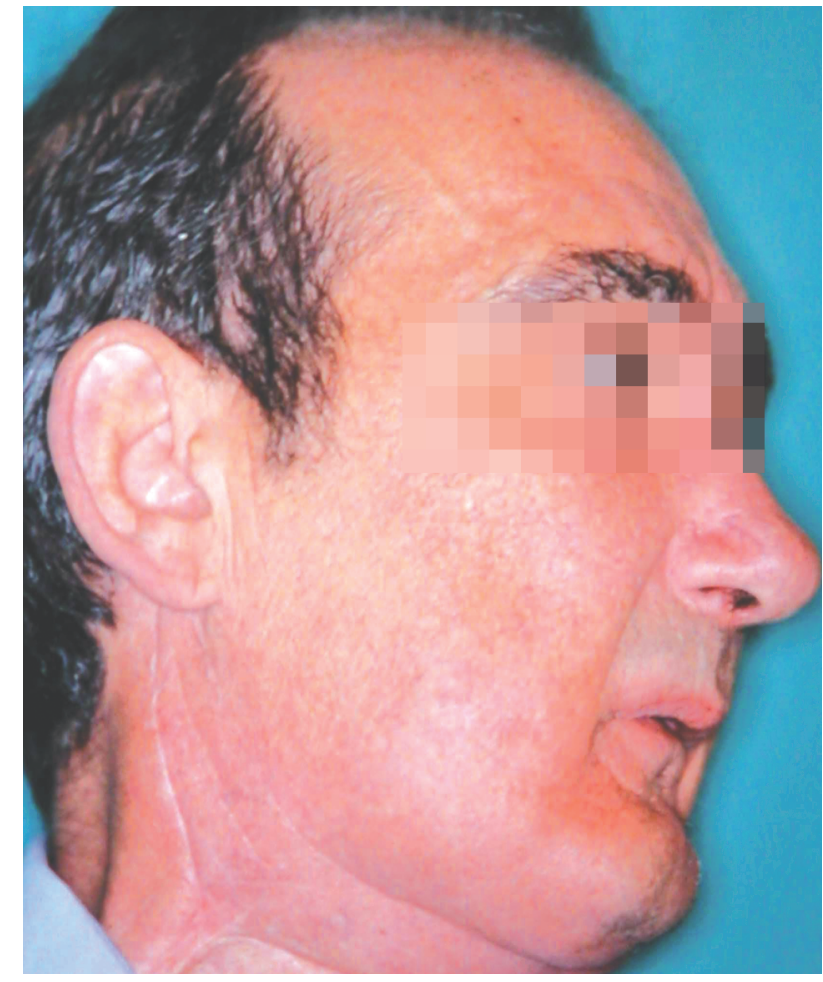

Figura 7. Resultado postoperatorio (vista de perfil). Figure 7. Postoperative result (side-on view).

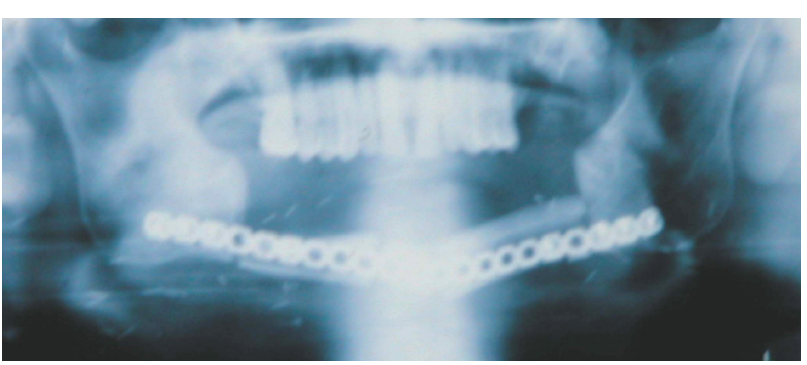

Figura 8. Ortopantomografía postoperatoria del caso 2. Figure 8. Postoperative orthopantomography of case 2.

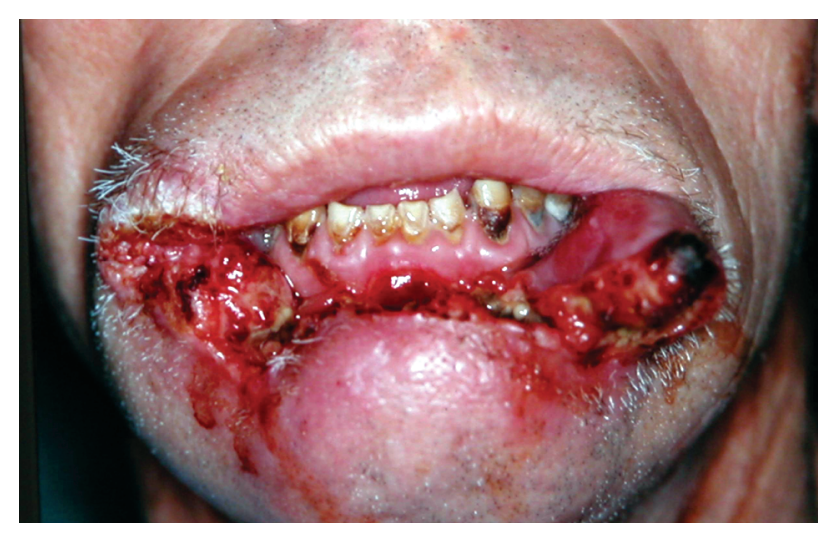

Figura 9. Caso 3. Carcinoma epidermoide de labio inferior. Figure 9. Case 3. Squamous cell carcinoma of lower lip. olar border and anterior floor of the mouth. The fibula was adapted to the mandibular form. Two osteotomies were carried out in order to leave three bone fragments, which were fixed to the reconstruction plate using screws. The fibula fasciocutaneous flap was used for reconstructing the lingual defect (Fig. 8). The histopathological result was reported as being moderately differentiated squamous cell carcinoma that did not reach the resection margins. Later radiotherapy treatment was started.

Case 3: Male patient 54 years old with a schizophrenic background. He had squamous cell carcinoma on his lower lip, which extended to the commissures, cheek and mandibular symphysis. Reconstruction was carried out with two simultaneous flaps: fibula osteocutaneous flap for mandibular symphysis, alveolar border and part of the floor of the mouth and radial forearm fasciocutaneous flap with a palmaris longus tendon for the internal and external surface of the lower lip, commissures, part of the cheek and chin. A bilateral supraomohyoid neck dissection was carried out. The resection included all the lower lip, both commissures, part of the right cheek, skin of the chin and part of the cervical skin under the chin, and the mandible from the premolar area on the right to the left premolar area. In this case, given the vestibular extension of the tumor, a resection of the mandible was carried out and later a mandibular reconstruction plate was adapted, taking as a refer- 
hubo ninguna complicación derivada de las zonas donantes. El lecho radial y peroneo se cubrieron en todos los casos con injerto cutáneo de espesor parcial.

Los resultados estéticos fueron valorados por los cirujanos y por el propio paciente, de acuerdo a la siguiente escala: excelente, bueno, regular y malo. El resultado estético de los dos primeros pacientes fue considerado excelente tanto por los cirujanos como por los propios pacientes. El resultado estético del tercer paciente fue considerado entre bueno y regular por los cirujanos y bueno por el propio paciente.

El primer paciente desarrolló metástasis pulmonares a los cuatro años de la cirugía. El segundo paciente está libre de enfermedad seis años postoperatorio y el tercer paciente cambió de lugar de residencia y no acudió a revisiones posteriores.

\section{Discusión}

Muchos de los defectos creados tras la cirugía ablativa de cabeza y cuello pueden ser reconstruidos adecuadamente utilizando un solo colgajo. Sin embargo, hay pacientes en los que la combinación de un defecto mandibular amplio con un déficit tridimensional de partes blandas, superficie amplia de cavidad oral o defectos compuestos intra-extraorales hacen que no sea satisfactoria la reconstrucción con un solo colgajo.

Para la reconstrucción intraoral se requiere una cobertura delgada, plegable, adaptable a los contornos de la cavidad oral, que no dificulte la movilidad de la lengua y que no interfiera con una posible rehabilitación dental. Para la reconstrucción ósea mandibular se requiere un aporte óseo de suficiente grosor y espesor para permitir una rehabilitación dentaria posterior.

Para la reconstrucción ósea de defectos oromandibulares se dispone de colgajos de peroné, cresta ilíaca y escapular, que aportan suficiente cantidad de hueso para la rehabilitación dentaria, ${ }^{8}$ aunque las características del tejido blando de cada uno de ellos son distintas. El colgajo escapular aporta un segmento

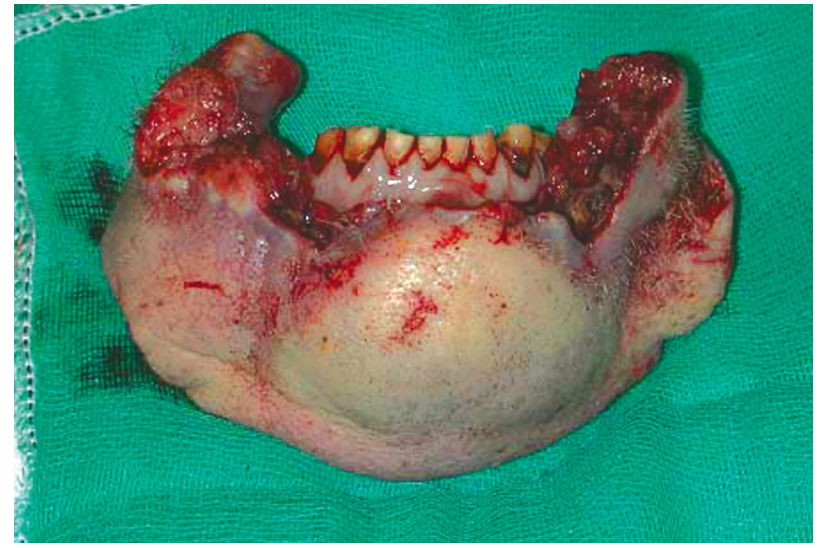

Figura 10. Pieza de resección. Figure 10. Resection sample.

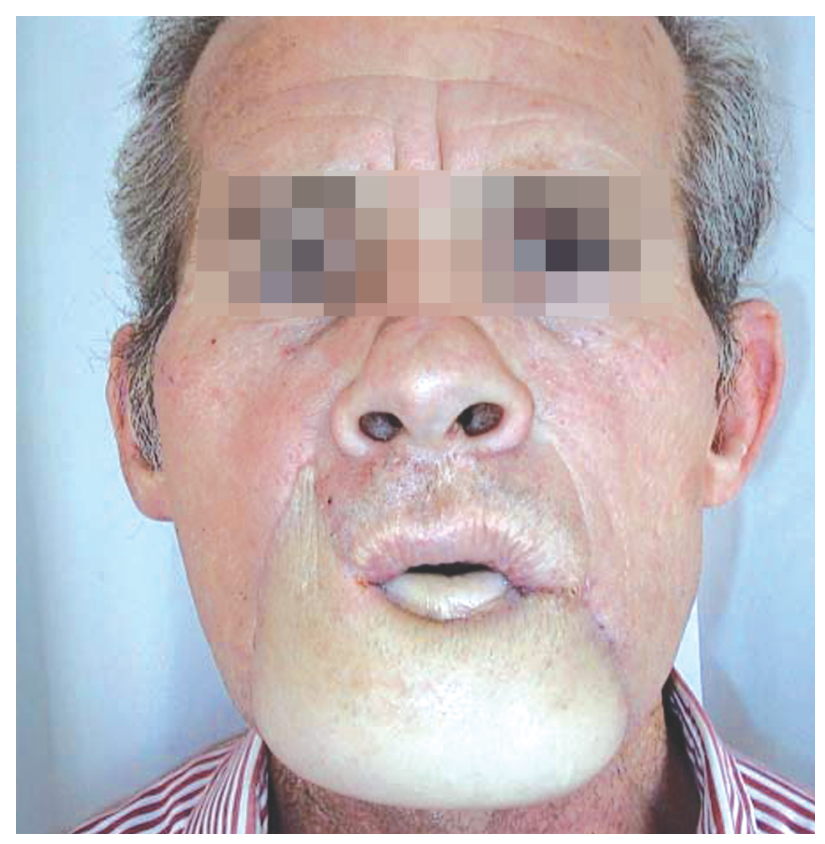

Figura 11. Aspecto final (vista de frente). Figure 11. End result (front-on view).

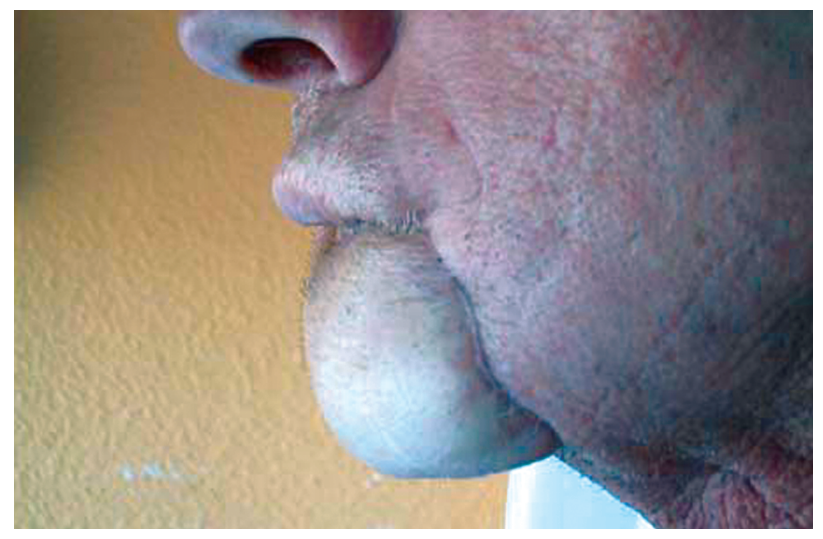

Figura 12. Aspecto final (vista de perfil). Figure 12. End result (side-on view). ence the maxillomandibular relationship in occlusion. Two osteotomies were carried out in order to place the fibula bone in the defect. Osteosynthesis of the fragments using the plate was carried out with screws. Anastomosis is then carried out of the peroneal vessels to the receptor vessels on the left side of the neck (lingual artery, external jugular artery and thyro-lingualfacial trunk vein). Anastomoses of the vessels of the radial flap were carried out to the receptor vessels on the right side of the neck (superior thyroid artery, external jugular vein and thyro-lingual-facial trunk vein). Following this the softtissue were sutured and the skin of the radial flap folded to form the lower lip. The palmaris longus tendon was used to suspend the soft-tissue of the new lip so as to avoid labial incompetence. He later underwent radiotherapy.

\section{Results}

The results have been analyzed by assessing the duration of the surgery, the survival of the flaps, complications, the need for secondary surgery, swallowing function, oral competence, diet, need for a permanent tracheotomy, phonatory function, morbidity at the donor site, aesthetic [results] and evolution of the disease. The average length of all the surgery was 11.5 hours. Postoperative evolution was favorable as none of the flaps were lost. Patient 1 developed an infection of the surgical bed on the left 
óseo de 10 a $12 \mathrm{~cm}$ en varones adultos y de $10 \mathrm{~cm}$ en mujeres y un espesor que oscila de 1 a $3 \mathrm{~cm}$. Con el colgajo de cresta ilíaca se pueden transferir hasta $12-14 \mathrm{~cm}$ de longitud. El peroné es el que aporta la mayor longitud de hueso para reconstruir la mandíbula (hasta $20-25 \mathrm{~cm}$ ), pudiendo reconstruir la totalidad de ésta. En la reconstrucción oromandibular, las superficies cutáneas de los colgajos osteocutáneos de peroné y de cresta ilíaca poseen un arco de rotación restringido respecto al componente óseo, limitando su aplicación como colgajo único en determinados defectos complejos. ${ }^{8}$ Los colgajos del sistema escapular tienen una mayor flexibilidad respecto al tejido blando que aportan, pero requiere reposicionar al paciente intraoperatoriamente y no es posible utilizar simultáneamente dos campos quirúrgicos, con lo que se alarga el tiempo quirúrgico. ${ }^{8}$ Además, la calidad del hueso escapular es peor en relación a la tasa de implantabilidad respecto al peroné y cresta ilíaca (el de cresta ilíaca es el que aporta la mayor tasa de implantabilidad). Para reconstruir defectos de superficie mucosa el tejido ideal debe ser un tejido delgado, flexible y adaptable a los contornos y superficies de la cavidad oral. Esto se puede conseguir con el colgajo fasciocutáneo de radial, lateral de brazo y lateral de muslo. ${ }^{8}$

Existen diversas publicaciones utilizando simultáneamente dos colgajos libres en reconstrucción oromandibular. Se han asociado la cresta ilíaca con el colgajo radial;5,12 el colgajo osteocutáneo de escápula con el radial; 6,12 el peroné con el radial o el lateral del brazo; 1,2,13,14 y el peroné con anterolateral de muslo.9,10,15 También, hay descritas asociaciones de dos colgajos libres para reconstrucción de partes blandas: radial bilateral para cavidad oral; ${ }^{2}$ para esófago; ${ }^{16}$ para defectos de tercio medio tras heridas por arma de fuego ${ }^{17}$ y dos colgajos de TRAM para restaurar el contorno facial. ${ }^{18}$ Asimismo, hay publicaciones de tres colgajos libres microvascularizados simultáneos: peroné con dos radiales, ${ }^{14}$ e incluso de cinco colgajos libres microvascularizados: radial bilateral, gracilis bilateral inervado y miocutáneo de recto abdominal. ${ }^{19}$

De todas estas posibles combinaciones la asociación de peroné y radial tiene una serie de ventajas. Permite intervenir al paciente en posición supina sin tener que cambiar al paciente de posición disminuyendo el tiempo quirúrgico. La elevación del peroné deja escasa morbilidad en la zona donante y aporta longitud adecuada para reconstruir defectos mandibulares extensos. En cuanto a las partes blandas, el colgajo radial posee un pedículo mucho más largo y de mayor calibre que el lateral de brazo. Aporta una piel delgada y plegable que lo hacen ideal para reconstruir defectos intraorales ya que preserva la movilidad lingual de la lengua remanente en las reconstrucciones de suelo de boca o lengua después de una glosectomía parcial y facilita la rehabilitación dentaria posterior en reconstrucciones del reborde alveolar. ${ }^{2}$

Existen variaciones según los autores en la forma de realizar las anastómosis de los dos colgajos libres. Unos autores prefieren la anastómosis secuencial o en "puente", actuando el colgajo óseo de conductor de flujo para el colgajo cutáneo y permitiendo entonces al colgajo cutáneo actuar como de "monitor" para el colgajo óseo. ${ }^{1}$ Otros autores reservan esta técnica para situaciones en las que la presencia de cirugía previa o radioterapia han disminuido el número disponible de vasos receptores.6,12 El peligro inherente a los colgajos libres secuenciales es que la trombosis en el primer col- side of the neck that was resolved with conservative treatment.

No secondary surgery was carried out. Swallowing function was adapted with no need for intubation. Oral diet was begun 10-15 days following surgery. Extubation was carried out 10 days after surgery. Oral competence, which was evaluated using drooling (absent, mild, moderate or severe) was adequate, with the absence of drooling in the fist two patients, and mild drooling in the third patient. Speech, which was evaluated as excellent (normal), good (easily intelligible), regular (understood with difficulty) and bad (unintelligible), was good in patient 2 and 3, and regular in patient 1. There were no complications in the donor sites. The radial and fibula bed were resurfaced in all cases with cutaneous grafts of partial thickness.

The aesthetic results were evaluated by surgeons and by the patients themselves, according to the following scale: excellent, good, regular and bad. The aesthetic results of the first two patients were considered excellent by the surgeons as well as by the patients. The aesthetic result of the third patient was considered between good and regular by the surgeons and good by the patient himself.

The first patient developed lung metastasis four years after surgery. The second patient is free of disease six years after surgery and the residence of the third patient changed and he did not attend later check-ups.

\section{Discussion}

Many of the defects created after ablative surgery of the head and neck can be reconstructed adequately using a single flap. However, there are patients in which the combination of a large mandibular defect with a tridimensional defect of soft-tissue, or covering a considerable area in the oral cavity or with composite intra-extraoral defects, leads to reconstruction with a single flap not being satisfactory.

For intraoral reconstruction a fine, pliable, adaptable surface is needed, which is adaptable to the oral cavity environment and that does not hinder the movement of the tongue, nor interfere with possible dental rehabilitation. For osseous reconstruction of the mandible a bone with sufficient thickness and width is required so that dental rehabilitation can later be carried out.

For bone reconstruction of oromandibular defects fibula, iliac crest and scapula flaps are available. They supply a sufficient amount of bone for dental rehabilitation, 8 even though their soft tissue characteristics are all different. The scapula flap provides a bone segment between 10 and 12 $\mathrm{cm}$ in adult males and $10 \mathrm{~cm}$ in women with a thickness that varies between 1 and $3 \mathrm{~cm}$. With the iliac crest 12-14 $\mathrm{cm}$ in length can be transferred. The fibula provides the longest bone for mandibular reconstruction (up to 20-25 $\mathrm{cm}$ ), and the mandible can be reconstructed completely with it. In oromandibular reconstruction, the skin surface of the 
gajo (colgajo conductor) pone en peligro dos colgajos. Urken refiere una pérdida de dos colgajos de un total de 20 colgajos utilizados en 10 pacientes, ${ }^{5}$ y Wells una pérdida de seis colgajos de un total de 20 colgajos (en 10 pacientes con colgajos dobles). ${ }^{14}$ Nosotros, al igual que Urken y Serletti, creemos que las ventajas que añade esta técnica están sobrepasadas por el riesgo y sólo estaría indicado cuando no hay disponibilidad de vasos receptores. ${ }^{1,5}$ Recientemente ha sido publicada una clasificación según la forma de conectar distintos colgajos libres: Colgajos puente, colgajos quimera, colgajos siameses, colgajos mosaico y colgajos en cadena circular. ${ }^{20}$

El tiempo quirúrgico total de la ablación y reconstrucción con dos colgajos microquirúrgicos dura una media de 10 a 12 horas según los datos de la literatura, ${ }^{5}$ y los de los casos presentados. Este tiempo es aproximadamente dos horas más de duración que cuando se utiliza un solo colgajo libre microvascularizado compuesto.

Para conseguir unos resultados funcionales adecuados es fundamental realizar la suspensión adecuada de los tejidos blandos al hueso (suspensión de musculatura perihioidea a basilar mandibular, suspensión de tejidos de piel y subcutáneo del mentón a la cara anterior mandibular, suspensión de comisuras por medio del tendón palmar largo para conseguir competencia labial). La reinervación sensitiva del colgajo radial puede mejorar los resultados funcionales de las grandes reconstrucciones. Con esta finalidad, en defectos complejos de mandíbula, lengua o labio se asocia al colgajo de cresta ilíaca o de peroné un colgajo sensitivo libre de radial anastomosándolo al nervio lingual o dentario inferior según las necesidades.5,11 El otro factor importante a considerar para conseguir resultados funcionales es que se debe mantener la movilidad de la lengua residual. Esto se consigue aportando un tejido plegable, flexible, delgado y adaptable a la superficie de la cavidad oral como el colgajo radial, el lateral de brazo, lateral de muslo y del dorso del pie. ${ }^{5}$

El autotrasplante simultáneo del colgajo radial y de peroné ha permitido reconstruir defectos oromandibulares complejos en los que la reconstrucción con un solo colgajo hubiera tenido peores resultados estéticos y funcionales. Un colgajo solo de peroné hubiera reconstruido el defecto mandibular y la parte anterior del suelo de la boca pero hubiera dejado una grave disfunción lingual. La gran longitud del defecto mandibular descarta las otras opciones de reconstrucción ósea microvascularizada (cresta ilíaca, ${ }^{3}$ y escápula, 21,22). La utilización de dos equipos quirúrgicos hace que no se prolongue en exceso la intervención quirúrgica con dos colgajos libres.

La indicación más frecuente para reconstrucción con dos colgajos libres es los defectos oromandibulares donde la complejidad del componente de tejidos blandos requiere el uso de un tejido delgado, plegable y adaptable a la anatomía tridimensional de la cavidad oral además de tejido óseo para la reconstrucción mandibular. ${ }^{8}$

\section{Conclusiones}

La reconstrucción con dos y aún tres colgajos libres simultáneos está indicada cuando las necesidades reconstructivas son diversas, el defecto afecta a diferentes estructuras y no existe un colgajo simple que reúna todas las necesidades reconstructivas que se precisa. osteocutaneous flaps of fibula and iliac crest have a restricted arc of rotation with regard to bone component, and their use is limited to certain complex defects. ${ }^{8}$ The flaps of the scapular system are more pliable with regard to the soft-tissue they provide, but the patient needs to be repositioned intraoperatively and using both surgical sites simultaneously is not possible thus surgical time is extended. ${ }^{8}$ In addition to this, the scapula bone is worse with regard to implantability rates compared with the fibula and iliac crest (the iliac crest provides the highest rate of implantability). In order to reconstruct defects of the mucosal surface the ideal tissue should be a fine tissue which is pliable and which adapts to the contours and surfaces of the oral cavity. This can be achieved with the radial forearm fasciocutaneous flap, lateral arm and lateral thigh flaps. ${ }^{8}$

There are several publications in which two free flaps are used simultaneously in oromandibular reconstruction. Iliac crest has been used with the radial [forearm] flap; $;, 12$ the scapular osteocutaneous flap with the radial [forearm flap]; 6,12 the fibula with the radial [forearm] or the lateral arm [flaps]:1,2,13,14 and the fibula with anterolateral thigh [flap] $]^{9,10,15}$ Also described are combinations of two free flaps for the reconstruction of soft-tissues; bilateral radial [forearm flap] for the oral cavity; ${ }^{2}$ for the esophagus; 16 for defects of the mid-face following gunshot wounds 17 and two TRAM flaps for restoring facial contour. ${ }^{18}$ And in this respect there are publications of three simultaneous microvascular flaps: fibula with two radial [forearm flaps] ${ }^{14}$ and even five free microvascular free flaps: bilateral radial, bilateral innervated gracilis and myocutaneous of abdominal rectus. ${ }^{19}$

Of all these possible combinations combining the fibula and radial [flaps] has a series of advantages. The patient can be operated on in the supine position and as positional changes are not required, surgical time is reduced. The elevation of the fibula [flap] leaves little morbidity in the donor site and provides adequate length for reconstructing extensive mandibular defects. With regard to soft-tissue, the radial [forearm] flap has a much longer pedicle of greater caliber than that of the lateral arm [flap]. Its skin is fine and pliable which makes it ideal for reconstructing intraoral defects as, in reconstructions of the floor of the mouth or tongue after a partial glossectomy, the mobility of the remaining tongue is preserved, and dental rehabilitation is later facilitated when the alveolar border is recontructed. ${ }^{2}$

There are variations according to the authors as to the way in which anastomosis to the two free flaps should be performed. Some authors prefer sequential anastomosis or "bridging", with the bone flap acting as a conductor of fluids for the skin flap, which then allows the skin flap to act as a "monitor" for the bone flap." Other authors reserve this technique for situations in which the presence of previous surgery or radiotherapy has diminished the number disposable receptor vessels. 6,12 The inherent danger of the sequential [connection] of free flaps is that thrombosis in the first flap (conductor flap) puts into danger both flaps. Urken 
La asociación de dos colgajos libres de peroné y radial está indicada en defectos oromandibulares complejos con gran longitud del defecto mandibular y de partes blandas para conseguir adecuados resultados funcionales y estéticos.

\section{Bibliografía}

1. Serletti JM, Coniglio JU, Tavin E, Bakamjian VY. Simultaneous transfer of free fibula and radial forearm flaps for complex oromandibular reconstruction. J Reconstr Microsurg 1998;14:297-303.

2. Kirn DS, Finical SJ, Kenady DE. Bilateral radial forearm free flaps for oral-cavity reconstruction. J Reconstr Microsurg 1998;14:551-3.

3. Urken ML. Composite free flaps in oromandibular reconstruction. Review of the literature. Arch Otolaryngol Head Neck Surg 1991;117:724-32.

4. Granick M, Newton D, Hanna D. Scapular free flap for repair of massive facial composite defects. Head Neck Surg 1986;8:436-41.

5. Urken ML, Weinberg H, Vickery C, Aviv JE, Buchbinder D, Lawson W, Biller HF. The combined sensate radial forearm and iliac crest free flaps for reconstruction of significant glossectomy-mandibulectomy defects. Laryngoscope 1992;102:54358.

6. Yanagiya K, Takato T, Akagawa T, Harii K. Reconstruction of large defects that include the mandible with scapular osteocutaneous and forearm flaps: report of cases. J Oral Maxillofac Surg 1993;51:439-44.

7. Sanger JR, Yousif NJ, matloub HS, Larson DL, Sewall SS. Reconstruction of lower third of face with three simultaneous free flaps. Plast Reconstr Surg 1994;94:70913.

8. Blackwell KE, Buchbinder D, Biller HF, Urken ML. Reconstruction of massive defects in the head and neck: the role of simultaneous distant and regional flaps. Head \& Neck 1997;19:620-8.

9. Ao M, Asagoe K, Maeta M, Nakagawa F, Saito R, Nagase Y. Combined anterior thigh flaps and vascularised fibular graft for reconstruction of massive composite oromandibular defects. Br J Plast Surg 1998;51:350-5.

10. Wei FC, Celik N, Chen HC, Cheng MH, Huang WC. Combined anterolateral thigh flap and vascularized fibula osteoseptocutaneous flap in reconstruction of extensive composite mandibular defects. Plast Reconstr Surg 2002;109:45-52.

11. Kuzon WM, Jejurikar SJ, Wilkins EG, Swartz WM. Double free-flap reconstruction of masive defects involving the lip, chin, and mandible. Microsurgery 1998;18:3728.

12. Nakatsuka T, Harii K, Yamada A, Ueda K, Ebihara S. Dual free flap transfer using forearm flap for mandibular reconstruction. Head Neck 1992;14:452-8.

13. Sanger JR, Matloub HS, Yousif NJ. Sequential conection of flaps: A logical approach to customized mandibular reconstruction. Am / Surg 1990;160:402-4.

14. Wells MD, Luce EA, Edwards AL, Vasconez HC, Sadove RC, Bouzaglou S. Squentially linked free flaps in head and neck reconstruction. Clin Plast Surg 1994;21:5967.

15. Koshima I, Hosoda S, Inagawa K, Urushibara K, Moriguchi T. Free combined anterolateral thigh flap and vascularized fibula for wide through-and-through oromandibular defects. J Reconstr Microsurg 1998;14:529-34.

16. Chen HC, Tang YB, Noordhoff MS. Reconstruction of the entire esophagus with "chain flaps" in a patient with severe corrosive injury: case report. Plast Reconstr Surg 1989;84:980-4.

17. Duffy FJ, Gan BS, Israeli D, Tantillo MB, Yaremchuk MJ. Use of bilateral folded radial forearm free flaps for reconstruction of a midface gunshot wound. / Reconstr Microsurg 1998;14:89-96. reports the loss of two flaps out of a total of 20 flaps used in 10 patients 5 and Wells a loss of six flaps out of a total of 20 flaps (in 10 patients with double flaps). ${ }^{14}$ Like Urken and Serletti, we feel that the advantages that this technique provides are outweighed by the risks, and that it should only be used when receptor vessels are not available. ${ }^{1,5}$ Recently a classification has been published with the form in which free flaps should be connected: bridge, chimeric, Siamese, mosaic and chain-circle flaps. ${ }^{20}$

The total surgical time of ablation and reconstruction with two microsurgical flaps takes an average of 10 to 12 hours according to data in the literatures and of the cases presented. This time is approximately two hours longer that when a single composite free microvascularized flap in used.

In order to achieve adequate functional results, suspending soft-tissue from the bone adequately is fundamental (suspending the perihyoid muscles from the mandibular base, suspending skin and subcutaneous [tissue] from the anterior mandibular surface, suspending the commissures using the palmaris longus tendon in order to achieve lip competence). Sensate re-innervation of the radial flap can improve functional results in extensive reconstructions. With this end, in complex defects of the mandible, tongue or lip, the iliac crest or fibular flap is connected with a sensate radial forearm free flap performing anastomosis to the lingual nerve or inferior dental [nerve] according to the requirements. 5,11 The other important factor to keep in mind is that, in order to achieve functional results, the mobility of the residual tongue should be maintained. This is achieved by transferring a pliable, flexible, fine and adaptable tissue to the surface of the oral cavity such as the radial, lateral arm, lateral thigh and dorsal foot flap. ${ }^{5}$

The simultaneous autotransplantation of the radial and fibula flaps has allowed complex oromandibular defects to be reconstructed where reconstruction with a single flap would have resulted in worse aesthetic and functional results. A single fibula flap could have been used to reconstruct the mandibular defect and the anterior part or the floor of the mouth but a severe lingual dysfunction would have remained. The considerable length of the mandibular defect rules out other options for microvascular bone reconstruction (iliac crest $^{3}$ and scapula ${ }^{21,22}$ ). Using two surgical teams means that surgical time is not prolonged excessively with two free flaps.

The most frequent indications for the reconstruction with two free flaps is for oromandibular defects in which the complexity of soft-tissue component requires the use of a thin, pliable tissue which adapts to the tridimensional anatomy of the oral cavity in addition to bone tissue for mandibular reconstruction. ${ }^{8}$

\section{Conclusions}

The reconstruction with two or even three simultaneous free flaps is indicated when reconstructive requirements 
18. Goossens S, Coessens B. Facial contour restoration in Barraquer-Simons syndrome using two free TRAM flaps: presentation of two case reports and longterm follow-up. Microsurgery 2002;22:211-8.

19. Burt JD, Burns AJ, Muzaffar AR, Byrd HS, Hobar PC, Beran SJ, Adams WP Jr, Kenkel JM. Total soft-tissue reconstruction of the middle and lower face with multiple simultaneous free flaps in a pediatric patient. Plast Reconstr Surg 2000;105: 2440-7.

20. Koshima I. A new classification of free combined or connected tissue transfers: introduction to the concept of bridge, siamese, chimeric, mosaic, and chaincircle flaps. Acta Med Okayama 2001;55:329-32.

21. Acero Sanz J, Concejo Cútoli C, de Paz Hermoso V, Fernández-Alba Luengo J, Verdaguer Martín JJ, Navarro Vila C. Reconstrucción mandibular asociada a grandes defectos de partes blandas. Versatilidad del colgajo osteofasciocutáneo escapular. Rev Esp Cirug Oral Maxilofac 2001;23:81-9.

22. Rodriguez Ruiz JA, Rendón Infante I, Torres Garzón L, Modelo Pérez A, Budiño Carbonero S, Fortis Sánchez E. Reconstrucción oral mediante colgajos microvascularizados basados en la arteria subescapular. Rev Esp Cirug Oral Maxilofac 2001;23:284-93. are diverse, the defect affects different structures and there is no simple flap which encompasses the entire reconstructive requirement.

The connection of two free fibula and radial flaps is indicated for complex oromandibular defects, with very long mandibular and soft-tissue defects, in order to achieve adequate functional and aesthetic results. 